\title{
Appraisal of Tipu Sultan's Contributions Toward Development of Unani Medicine: A Critical Analysis
}

Mohd A. ALi' ${ }^{1}$, Mohd A. BAKAR², Mohammad ASLAM³, Mohd KHALID ${ }^{4}$, Abdul A. FARIS ${ }^{5}$, Hamiduddin ${ }^{6}$

\footnotetext{
${ }^{1}$ Department of IImul Saidla, National Institute of Unani Medicine, Bangalore, Karnataka, India.

${ }^{2}$ Department of Kulliyat, National Institute of Unani Medicine, Bangalore, Karnataka, India.

${ }^{3}$ Department of Tahaffuzi wa Samaji Tib, National Institute of Unani Medicine, Bangalore, Karnataka, India.

${ }^{4}$ CCRIUM, Hyderabad, Telangana State, India.

${ }^{5}$ Department of Ilaj Bil-Tadbeer, National Institute of Unani Medicine, Bangalore, Karnataka, India.

${ }^{6}$ Department of IImul Saidla, National Institute of Unani Medicine, Bangalore, Karnataka, India.
}

\section{ABSTRACT}

Unani system of medicine has enjoyed the status of being royal since antiquity, and various rulers and governments have paid special attention toward its growth and development. In India, Tipu Sultan, a highly cultured intellectual, academician, physician, scholar, and a great scientist, was one of those who played an important role in the advancement of Unani medicine. He had an imperial library located at Srirangapatna housing more than 2000 manuscripts in Arabic, Persian, Turkish, Urdu, and Hindi, dealing with medicine, military science, music, Hadith, law, Sufism, history, philosophy, grammar, astrology, poetry, and mathematics, of which 62 books were related to medicine. He also possessed vast expertise in treating various diseases, which is inferred from his personal letters and communications. He not only showed interest in preserving Unani manuscripts but also mentioned about 45 books on the subject of medicine in his memoirs. The health system was highly sophisticated in his territory among his contemporary kingdoms. Moreover, physicians and surgeons were regularly inducted to serve the injured and wounded soldiers in every battalion. The present study judiciously inspected the contributions of Tipu Sultan toward the patronage and promotion of Unani medicine, especially in the southern part of India in the $18^{\text {h }}$ century.

Key words: Imperial library; manuscripts; Tipu Sultan; Srirangapatna; Unani medicine.

\section{INTRODUCTION}

Tipu Sultan (1750-1799), also known as the Tiger of Mysore (1), was a man of intelligence and courage, a man of strong belief, a great warrior, a great scholar, a great scientist, and a great planner (2). He was one of the most powerful rulers of a well-administered kingdom (3). According to Mohibbul Hasan (b. 1909), Tipu was an "enlightened and tolerant ruler." (4) B. Sheik Ali (b. 1925) regarded Tipu Sultan as the "flair for modernization" (5) in the 18th century in India. He was a great man. Tipu often said that "it was far better to live like a lion for a day than to live like a jackal for hundred years." $(6,7)$.

He was born on November 10, 1750 (4,8) in Devanahalli, (9) also known as Yusufabad, a village $33 \mathrm{~km}$ far from the city of Bengaluru in south India. His father Haidar Ali (1722-1782), (10) although an illiterate, appointed talented teachers to give Tipu the usual scholastic education along with military training (4). According to Mohibbul Hasan (b. 1909), Tipu showed interest in science, medicine, music, astrology, and engineering, but calligraphy, theology, and Sufism served his favorite subjects (4). Moreover, he was ambitious of being an author (5) and wrote more than 45 books himself or translated from other languages under his supervision and patronage on the subjects of medicine, military science, Sufism, music, history, law, and Hadith (11). 
He was a great patron of scholars and poets (1). Hence, after coming to the power (1782), he established a university in Srirangapatna named as Dar-ul-Umur, also called Jami-ul-Umur or Jami-ul-Uloom, serving to the cause of education and research (12). He named this university Dar-ul-Umur for the purpose of advancement in arts, science, and technology. Therefore, all subjects of arts and science were in the syllabus (13).

Tipu evinced keen interest in collecting books in various languages, including Arabic, Indian, Persian, and European (9). He had an excellent library consisting of 2000 manuscripts in Arabic, Persian, Turkish, Urdu, and Hindi languages dealing with medicine, military science, music, Hadith, law, Sufism, history, philosophy, grammar, astrology, poetry, and mathematics $(4,5)$ and was regarded as the sign of excellence in the East (14). A librarian was appointed for maintaining and managing the library (12). A descriptive catalogue of the oriental library of the late Tipu Sultan of Mysore (SCRR ED80.29/9330) was published by Charles Stewart (1764-1837) in 1809, which contained 364 pages with a detailed description of the library of Tipu Sultan with its specifications (15). Charles Stewart listed 1090 manuscripts in different languages, but he mentioned more than 2000 manuscripts, some of them gifted to the Oxford and Cambridge Universities and to the Royal Asiatic Society of Bengal (1).

Molvi Amjad Ali Ashhari, in his book Savaneh Tipu Sultan (A Biography on Tipu Sultan), mentioned a catalog of the library of Tipu Sultan consisting of 1889 rare books and manuscripts, which were bounded by gold and precious stones. Many of them were gifted to the treasury of library by several governments and Islamic scholars, of which 62 books were on the subject of medicine (11).

After the fall of the kingdom of Tipu Sultan, the plunder and loot of his great library with literary treasures was the greatest loss to the nation. A person bought a manuscript for Rs. 5, which he sold later for Rs. 2000. Still, later it fetched $£ 250$, and the hand-written Quran by the Mughal Emperor Aurangzeb (1618-1707 AD) valued at Rs. 90,000 finally found its way to the Windsor Palace. The entire Library of Tipu Sultan first was shifted to the Fort William College, Calcutta, in 1800, and subsequently to England (1).

\section{CONSERVATION OF UNANI MEDICAL MANUSCRIPTS}

It shows the great interest and affection of Tipu Sultan toward Unani medicine that 62 books were related to medicine in his library (11). He also had good experience in treating various diseases, which is described in his personal letters and writings (16). He was also a writer of repute and fame (14). He not only preserved Unani manuscripts and their principles but also wrote about 45 books by himself or translated from other languages under his supervision and patronage on various subjects, (17) such as Tuzak-i Tipu, Zabarjad (a book on astrology), and a treatise on the preparation of perfumes and the art of dyeing and cleaning (5).

Some books preserved in the library of Tipu Sultan on the subject of medicine are mentioned below:

1. Khulasat-ut-Tibb: a short treatise on medicine, art of dyeing, and paper making written by Muhammad bin Masood $(11,18)$.

2. Asrar-e-Attiba: essays on the virtues of amulets, medicine, and charm for averting diseases authored by Shihab ad-Din $(11,18)$.

3. Shifa ar-Rijal: a poetical treatise on medicine by Shihab ad-Din $(11,18)$.

4. Bahr-ul-Manafe': the book, written by Maulood Muhammad in 1794 on the order of Tipu Sultan and dedicated to him, discusses embryology, with a special focus on the birth and care of the child; the book also contains a chapter on hygiene $(1,11)$.

5. Qanun-dar-IIm-e-Tibb: A compendium (complete pharmacopeia of London Hospital) of reputed European physicians on medicine translated from English to Persian by order of Tipu Sultan $(1,11,18)$.

6. Tarjuma Kitab-i-Farang: A translation of Dr. Cook Burn's treatise on a twist of the intestines $(11,18)$.

7. Mufradat dar-IIm-e-Tibb: It is a book on medical science and natural history translated by order of Tipu Sultan from French and English into Persian, in which various herbs and roots of plants of medicinal properties are described. It contains diagrams and pictures of plants, with the references from English and French sources. Charles Stewart adds a note that Tipu Sultan used English prisoners for translating and compiling this book $(1,11,18)$. 
8. Tibb-e-Darajan: This book was compiled by order of Tipu Sultan on the subject of medicine; one manuscript of the book is preserved in the Oriental Research Library, Mysore, with many signatures of Tipu Sultan on its initial pages $(11,18)$.

9. Barqi wa Tibbi Tajurbat: The book discusses experiments on electricity and medical treatments; this book was translated from English to Persian under the patronage of Tipu, taken from "Cockburn's Twist of Intestines." (1,11).

10. Tohfa-e-Muhammadi: This book was written by Muhammad Naseer Ifshar Turk on behest of Tipu Sultan on pharmacology dealing with different drugs with details of the treatments of various diseases, dedicated to the Sultan, arranged in Arabic alphabetical order $(1,11)$.

11. Hukm Namah: This book was written under the patronage of Tipu Sultan on rules and regulations of the Kingdom; one chapter was especially for illustration of tobacco prohibition for public as well as military and description of its harmful effects on health $(13,19)$.

12. Tohfat-ul-Mujahedeen: The book was dictated by Tipu Sultan to his courtier Mir Zainul Abidin Shustry in 1783 on the subject of military sciences divided into eight chapters; in the appendices of the book, management of diseases such as dog bite, snake bite, and scorpion bite has been briefly dealt with.

Snake Bite: 1) Ankola roots [Alangium salviifolium (L. f.)] in powder form; one hawen (a unit of weight) to be taken orally with water and applied on the wound locally.

2) The extract of shaali (Oryza sativa L.) root (dry or wet) should be used orally [one Kaddah (a unit of volume)]; more than one Kaddah may be poisonous to the body.

3) Samandar phal (an Indian-origin drug such as chebulic myrobalan in square shape); one hawen (a unit of weight), ground and mixed with cold water, should be taken orally and applied on the wound topically.

Dog Bite:Small black acacia, which bears beans and yellow flowers; the beans, bark, and root of this acacia should be ground in curd of cow milk and taken orally for 5 days in the morning. Moreover, this preparation may be served as a diet to the patient; only curd should be given to the patients for drinking instead of water.
Scorpion Bite: The three leaves of coffee senna (Kasondi, Cassia occidentalis Linn.) should be taken orally, and the same in the powdered form may be used topically on the affected site $(12,13)$. If someone is bitten by a rat, the body develops nodules and pustules. It should be treated with one or two films of snake shedding along with jaggery four times a day internally. This prescription is also beneficial in other skin diseases.

According to Mahmud Bangalori (1887-1958 AD), this book indicates that the systems and regulations of the kingdom of Tipu were well developed (13).

The book is in Persian language, and its Urdu translation was rendered by Dr. Mahmud Husain Khan (1907-1975) and published from Pakistan in 1950. A single Persian manuscript of this book (manuscript No. 1250) is also available in the Asiatic Society Bengal, Calcutta (12,20). According to Maktoob-e-Sultani, some more European books on pharmacopeia and colicky pain were translated by order of Tipu the King (12).

\section{HEALTH SYSTEM INTHE KINGDOM OFTIPU (1782-1799)}

Tipu Sultan was a capable ruler and administrator. He did much to strengthen Mysore with contemporary science and improve the conditions of the peasantry (19). He did not stick to the old regulations but introduced a new system through all his dominions (21). A greatest contribution of Tipu Sultan was spreading awareness and consciousness among his people. His reforming zeal touched almost every strata of society. The health care system in the kingdom of Tipu was well established, developed, and popular. Although Tipu Sultan propagated and promoted Unani (GreecoArabian) medicine on preferential ground in his territory, he was never unaware of the advancement of Western medicine. Hence, one can always find a Western physician or surgeon beside Unani Hakeems. All Hakeems (physicians) were grown on the concept of temperament and humors, the core philosophy of Unani medicine (22). The kingdom of Tipu had many hospitals. Groups of Hindu, Muslim, and French physicians and surgeons were appointed for treating patients and providing health care facilities $(1,23)$. The wound was washed three to four times a day with simple warm water by a boy attendant. The surgery was done by Jarrah (surgeon) if required (22). 
In 1793, Tipu Sultan established Piadah Askar (foot soldiers) and Sawar Askar (Cavalry) in his army. Twenty-seven Cushoon (a battalion of foot soldiers) were established, and for every Cushoon, one Hakeem (physician) and one surgeon were appointed. In Sawar Ashkar (rider soldiers), especially veterinary surgeons were appointed along with Hakeems (physicians) and surgeons. In all departments (revenue, military, and so forth), health-related quality facilities were available and a group of physicians and surgeons was appointed. The salary of a Hakeem was five Pagodas (currency of Saltanat-e-Khudadad) per month, more than that of a surgeon who got three Pagodas per month (16).

According to the British assessment of Tipu Sultan's Hill Fort, Chiltaldrug had more military and garrison buildings. It also had some hospitals; the two larger hospitals located in the town were designated for the sepoys. It measured $200 \mathrm{ft}(61 \mathrm{~m})$ in square and $12 \mathrm{ft}(3.6 \mathrm{~m})$ in height, having mud walls with a roof. The inventory adds the note that it "was built in a square." Given its dimensions and roof type, it was likely a series of rooms built around an open courtyard. It too was judged to be in unserviceable condition. The survey report describes it as a $56 \times 44 \mathrm{ft}(17 \times 13 \mathrm{~m})$ mud-walled structure with a tiled roof (24). It is assumed that these hospitals were well established with all facilities. A series of rooms consisted of special and general wards. Some rooms were allocated especially for outdoor patients, and some were for specific treatment. Male wards were separate from female wards. More attention was given to wounded patients, called as emergency medical services. Skilled physicians and surgeons, pharmacists, and other hospital staff were appointed for smooth functioning of the hospital. This hospital was also mentioned in the archeological report of Mysore for the year 1935 (25).

According to Anwar Harun (b.1942), buildings of military magazine and the hospital were of main importance in Srirangapatnam (26).

Special rules and regulations were compiled for all departments including hospitals and health care officers for betterment of humanity and proper restoration of health. The book Hukm Namah, consisting of 14 volumes, was compiled under the immediate inspection of Tipu Sultan (27). Once chicken pox broken out in the camps of rebels. Tipu Sultan immediately ordered Badruzzaman
Khan Naita to transfer the rebels to a place suitable for their health. Tipu often said that "I have been born to soothe the wounds with ointment; hence I easily get horrified with murder and plunder of the mass." (11).

Tipu Sultan showed his concern for disabled subjects in his regulations of 1786. He proposed to employ the lame and blind "for blowing the Bellows of Iron Works" and the Amildar or Amil was ordered to give them "something for their traveling expenses too." (5).

Tipu Sultan gave great attention toward health education in his territory. The Dar-ul-Umur University was quite renowned for all the prevalent subjects, but Unani Tibb got a dignified position among the other subjects under the supervision of renowned physician of his time Hakeem Mohammad Baig, who also served as the royal physician of Saltanat-e-Khudadad (kingdom of Tipu) (11, 12); another Hakeem was Ghulam Husain Munajjim Aasi (11). The university was equipped with a well-established pharmacy and chemical laboratory for preparation, analysis, and experimentation of Unani drugs. According to Mahmud Khan Bangalori (18871958), a famous chemical laboratory in Srirangapatna was established for analysis and experimentation of drugs and other chemicals (12).

According to Mir Hussain Ali Khan Kirmani (d.1864), Tipu Sultan established schools and colleges in his treaty for Islamic and technical knowledge along with health education (28).

Francis Buchanan-Hamilton (1762-1829), a traveler to Madras through Mysore, Canara, and Malabar in 1800 AD, mentioned in his book A Journey from Madras through the Countries of Mysore, Canara and Malabar about various colleges, hospitals, apothecary shops, physicians, surgeons, pharmacists, and cultivation and trading of medicinal plants, and awareness of people about health and many other facilities related to medicine. These indicated a well-established health care system in that time (29).

Tipu also appointed Saidalani (pharmacists) and established apothecary shops under his government supervision. He developed a prosperous health care system equipped with the facilities and technologies of his time (16). 


\begin{tabular}{|c|c|c|}
\hline S. No. & Diet & Quantity \\
\hline 1 & Rice & $3 / 4$ of a full Duk or Seer (960 g) \\
\hline 2 & Dal (or split peas) & $1 / 4\left(d^{\circ}\right)$ \\
\hline 3 & Ghee & $\begin{array}{l}8 \text { Jouz weight (weight of eight } \\
\text { nutmegs) }\end{array}$ \\
\hline 4 & Meat & $1 / 2$ short Duk or Seer $(960 \mathrm{~g})$ \\
\hline 5 & Salt & $\begin{array}{l}3 \text { Jouz weight (weight of three } \\
\text { nutmegs) }\end{array}$ \\
\hline 6 & Tamarind & $2\left(d^{\circ}\right)$ \\
\hline 7 & Turmeric & $1 / 2\left(d^{0}\right)$ \\
\hline 8 & Dry garlic & $1 / 2\left(d^{0}\right)$ \\
\hline 9 & Onions & $1 \frac{1}{2}\left(d^{0}\right)$ \\
\hline 10 & Coriander seed & $1 / 4\left(d^{\circ}\right)$ \\
\hline 11 & Black pepper & $1\left(d^{\circ}\right)$ \\
\hline
\end{tabular}

\begin{tabular}{|c|c|c|}
\hline S.No & Diet & Quantity \\
\hline 1 & Rice & 1 of a full Duk or Seer (960 g) \\
\hline 2 & Dal (or split peas) & $\begin{array}{l}6 \text { Jouz weight (weight of six } \\
\text { nutmegs) }\end{array}$ \\
\hline 3 & Ghee & $4\left(d^{\circ}\right)$ \\
\hline 4 & Salt & $2\left(d^{\circ}\right)$ \\
\hline 5 & Tamarind & $2\left(d^{\circ}\right)$ \\
\hline 6 & Turmeric & $1 / 2\left(d^{0}\right)$ \\
\hline 7 & Dry garlic & $1 / 2\left(d^{0}\right)$ \\
\hline 8 & Onions & $1 \frac{1}{2}\left(d^{\circ}\right)$ \\
\hline 9 & Coriander seed & $1 / 4\left(d^{0}\right)$ \\
\hline 10 & Black pepper & $1\left(d^{\circ}\right)$ \\
\hline
\end{tabular}

The kingdom of Tipu had a provision for balanced diet with special menu according to the need of the physical activities especially for military personnel. All the officers, including Hakeem (physician) and Jarrah (surgeon), had to eat together. The rations were to be served to all officers on a daily basis (Table 1) (16). The rations provided to the Musqueteers (Navy commander) and gunners were distributed with some differences in their quantities, especially meat (Table 2) (16).

Tipu knew well about the harmful substances for health and society. So, he began to restrict and regulate the conduct of the shops for the sale of spirituous liquor, and finally and effectually abolished the whole in 1784 along with the sale of all intoxicating and destructive substances such as poppy flowers (Papaver somniferum Linn.), and the Bhang (hemp plant, Cannabis sativa Linn.) even in the private gardens $(21,22)$. According to Lewin Bentham Bowring (1824-1910), "Tipu's prohibition of intoxicating drug is an act of reformer." (30).

Tipu mentioned prohibition in the first chapter of the book Tuhfah tul-Mijahideen (13). He prohibited the cultivation of red pepper and vine due to cutaneous eruptions and alcohol intoxication in the maritime districts. The growth of pepper was permitted later for purposes of its medical regimen and trading with the Arab World. Some items such as tobacco, sandalwood, pepper, and precious metals were bought under state permit only (19). Colonel Mark Wilks FRS (1759-1831), writer of History of Mysore, stated "I could not determine whether the prohibition of growing red pepper or chili, was to be considered as a commercial regulation to increase the growth of black pepper or as a medical regimen or as a compound of both motives." (22).

Tipu propagated the production of silkworm and other agricultural products for medicinal and economical purposes (31). In another letter, he spoke about the cultivation of saffron (32). According to MarkWilks (1759-1831), Jaiphal (Myristica fragrans Houtt.) is also imported from Travancore and cultivated in Lal Bagh for spices ad medicinal purpose (22). Now Mysore is a good exporter of nutmeg in India (13).

According to Francis Buchanan-Hamilton (1762-1829), the cultivation and production of medicinal plants and herbs were common in large scale. Especially sandal wood and cardamom were items of external commerce. The trade between the dominions mostly comprised salt, sulfur, tin, lead, zinc, copper, indigo, nutmeg, cloves, camphor, a hot root used in medicine, China root, and so forth (29). The cultivation of crops, medicinal herbs, and other plants was allowed in dry lands given at a fixed rent (21).

Whenever Tipu heard of something new, he wanted it for Mysore (32). He stood for a change from traditionalism to modernism. He had deep interest in a revolutionary change in every sector of life (1). He set up, within the span of few years, truly astonishing 
factories in Srirangapatna, Chiltaldrug, Bangalore, and Bendur (4) for manufacturing items related to the health care system and other departments, such as scissors, scientific instruments, watches, cutlery, hour glasses, paper mill, glassware unit, and military-related equipment. Hundreds of foreign technicians were brought in, including Frenchmen, Germans, Turks, Arabs, and Chinese, bringing with them their technical know-how and the vision of a modern world $(6,32)$.

Tipu Sultan had keen interest in trading of some mineral drugs used in Unani medicine, such as sulfur, lead, copper, and so forth, from Muscat. He established pearl industry, and training was done in several places for procurement. All types of oil extraction, medicinal and nonmedicinal, especially sandalwood oil, were common $(1,13)$. Tipu Sultan also established a sugar factory at Channapatna in which white sugar was prepared in good quality that was assumed to be better for the health in that time (13). These examples indicated strong relation and great affection of Tipu Sultan toward Unani medicine. On the contrary, he had innovative ideas in medicine and war technology. He enriched Unani medicine with other systems of medicine such as French medicine, and for the same, he sent a delegation of physicians to France in 1787 to get acquainted with new experimental and observational research. Moreover, he invited a skillful physician, technicians, a dyer, and a pharmacologist thoroughly acquainted with, and capable of, preparing every kind of medicine known in Europe, and, lastly, an able surgeon from France, 1,16 which set the best example of being a modernist at a time when his contemporary rulers were in slumber. He also sent Meer Ghulam Ali to Turkey for alliance and ordered to bring up two experts of sulfur mineralogy and some experts of gold and silver mineralogy (13).

Hence, when Tipu Sultan came to know about a newly invented instrument that could measure body temperature accurately, he wrote to Francis, governor of Pondicherry, to provide the instrument to him and also send an instruction book in Persian for its accurate utilization $(12,22)$.

Two herbal gardens for experimental purpose at Srirangapatna and Bangalore, named as Lal Bagh, were established having nurseries in which seeds and saplings from different countries of the world were obtained and planted. A special plot was allotted for separate kind of fruits, trees, and herbs. The Lal Bagh of Srirangapatna disappeared with the fall of the kingdom of Tipu, but Lal Bagh of Bangalore is still present, which reflects great affection of Tipu toward advancement, development, research strategies in medicine, botany, and other sciences (4). The Lal Bagh was also used as bonsai. Therefore, numerous plants from all over the world were imported and experimented under different atmospheric conditions (13).

Tipu Sultan made special rules and regulations for health and hygiene. He ordered his officers for plantation in urban as well as rural areas that could consume polluted air. Occupations that caused pollution, for example laundry and dyeing, were transferred to outside the city (13).

Tipu Sultan established government orphanage in various places of the kingdom where the orphans availed all types of health care and other facilities for proper mental and educational development (13). A special health facility was available for prisoners also (33).

Tipu Sultan established animal husbandry named as Amrit Mahal. A group of talented veterinary doctors were appointed; in this department, cows, oxen, horses, mules, and elephants were hybridized and bred. Good resources were available for health care facilities for the animals (13).

He personally supervised every department of the Government. Colin Mackenzie (1754-1821) records that Tipu invigorated the whole system by principles of good government and an economic management of resources to which those of any neighboring power bore no comparison" (1). In the kingdom of Tipu, the people were happy because everything was available including patient care facilities and social welfare (34). It is said in Authentic Memoirs of Tippoo Sultan about the kingdom of Tipu"the men in general were healthy and robust; the women were more delicate, but strong and well made." (35).

\section{TIPU SULTAN AS A PHYSICIAN}

The personal letters of Tipu Sultan show that he possessed the potential to make precise diagnosis and good prescriptions. On various occasions, he advised prescriptions along with preventive measures of the diseases. He strictly followed health care rules and 
also ordered his officers for the same. He used to wake up early in the morning and go for morning walk regularly. He usually took fruits and milk in breakfast. He had restricted himself to only two meals in a day whole life (13). Tipu Sultan was quite caring toward his officers. The letters that he wrote to them contained affectionate words; he was solicitous for their health, and in case of their illness, he himself used to prescribe medicines for them (4).

In a letter to Meer Qamruddeen and Burhanuddeen, he said "you should consult the physician for your ill health." (16). In another letter to Mahommad Ghyas, he advised regimens for faster healing and gave valuable suggestions, which shows his affection toward his officers. These facts inferred that Tipu was bonded with Unani medicine through his sound knowledge on its principles such as Mizaj and Akhlat. He wrote in context of disease management that the first thing to be done was to draw all the Fasid Akhlat (morbific humors) by wet cupping, leading to faster improvement due to restoration of the normal Mizaj of the patient; the remnant morbific matter should be expelled out of the body with the judicious administration of drugs in view of the temperament of that patient (16).

In a special discourse with his military physician on a dog biting case, he directed the physician on duty to administer proper medicines without stopping the discharge from the lesion, and the wound to be kept open for 6 months $(11,22)$. According to William James Kirkpatrick (1838-1921), the translator of Tipu Sultan's letters, this was not the only letter in which the Sultan exhibited himself in the character of a physician; still more curious instances of the same kind would appear hereafter. It would be judicious to dedicate his active indulgence in such issues to the welfare of the patients. This attribute might, at least, be credited to his soul of humanity, but humanity or sympathy in the sufferings of others is not found among the virtues of other rulers (16).

Addressing his ambassador to Pune territory, he quotes "you have mentioned in your communications about the environmental changes there, in this particular case, the designated physician should at first evacuate the morbific matters out of the body through wet cupping as it helps in restoration of health to its normalcy." (12).
It should be taken as a clinical case as Tipu the King advised camphor oil for the treatment of sciatica (irqun-nasa), as Mr Gulam Ali Khan, a military designate, was suffering from the same. He also provided two bottles of pure camphor oil, which was heavily cultivated in his territory (12).

Tipu was highly experienced and skilled in Nuskha Navesi (method of prescription). According to William Kirkpatrick with reference to the letter number 346, Sultan sent one Nuskha (prescription) of Sanoon (tooth powder) to the head of the police station Toshak Khana of Shrangapatnam and ordered that this prescription should be prepared and sent to Mahal Sarai and also to him" (12). Tipu Sultan proposed many prescriptions from his own intelligence. The physicians of that time were amazed after experiencing that prescription (11).

Tipu Sultan prescribed the treatment of vesicle stone to Chisti Yaar Khan with details of its ingredients, doses, duration, dosage form, method of preparation, and route of administration. This prescription illustrated the intellectuality, proficiency, ability, and expertise of Tipu Sultan in the field of Unani medicine. Tipu also sent by post an emetic drug to be taken on the first day, followed by other medicines for the seven subsequent days.

He further mentioned that during the course of treatment, the patient should avoid eating black and red pepper, and other hot and flatulent edibles. The diet should be curry of radish and boiled rice, and drink should be a solution of muskmelon seeds, cucumber seeds, and dry thorn. The stone would be flushed out in this way $(11,16)$.

In fact, after the fall of Srirangapatna, the valuable documents and important experimental records of Tipu Palace on medicine, especially Tajurbat-e-Sultani and Bustanul Aqaqeer, were lost. If these books were present today, they might have been helpful on the subject of medicine (12). The letters of Tipu Sultan are an important source of information on health care system in his era. William James Kirkpatrick (1838-1921), in-charge of the library of Tipu Sultan after the fall of his kingdom, published about 435 letters in 1811 AD from London, but these letters were far less than those made available by Prof. B. Sheik Ali (b.1925) from London to Vidhan Sudha Arcade, Bangalore, for preservation and research purposes. 


\section{CONCLUSION}

It is a notable point that most historians have not mentioned health care system of the kingdom of Tipu, whereas they have discussed other departments in elaborative and illustrative manners. It seems quite bizarre that the health care system was in dilapidated conditions where technological, warfare, and other developments were quite steady. On the contrary, the Madras Presidency under the British government had a highly developed health care system with medical education and laws. A great historical lacuna exists on the subject of health care system in Tipu's era, which should be critically quested for. Tipu Sultan was instrumental in the development of Unani medicine by appointing Unani physicians and pharmacists and establishing apothecary shops and Unani pharmacy for the preparation of drugs. In brief, he dedicated his entire life serving his subjects with utmost sincerity by promoting indigenous health care system in his territory. His valuable services and patronage toward Unani medicine proved to be highly potential in its promotion and advancement.

\section{ACKNOWLEDGMENT}

Co-authors; Prof. B Sheik Ali, a legend historian and Founder Vice-Chancellor of two new universities, Mangalore and Goa; Dar-Ul-Umoor (Tipu Sultan Advanced Study \& Research Center) Srirangapatna and its staff; National Institute of Unani medicine library staff; State Central Library, Cubbon Park; ad State Central Library, South Zone, Bangalore.

\section{REFERENCES}

1. Ali Sheik B. Tipu Sultan A Crusader for Change. Mysore: http:// www.bsheikali.in: 182,404,407.

2. Haider Ali and Tipu Sultan: A Brief Profile. http://shodhganga. inflibnet.ac.in:8080/jspui/bitstream.pdf. accessed on 23.06.2016.

3. Majmudar RK, Srivastava AN. History of Karnataka. Delhi. SBD publisher's distributers. 2006:27,273-277.

4. Hasan M. A History of Tipu Sultan. 1st ed. Calcutta Dacca: The Bibliophile LTD; 1951:9,10,341,374,379.

5. Kaveh Yazdani. Haidar 'Ali and Tipu Sultan: Mysore's Eighteenth-century Rulers in Transition. Itinerario, 38;2014:101-120.

6. Sampath Vikram. Splendours of Royal Mysore.Delhi. Rupa and company.2008. P.334.

7. Anonymous. Narrative Sketches of the Conquest of the Mysore. 2nd ed. London; W. Justins, Pembeiton Row, Gough Squnre, Fleet Street,:1800.
8. Anonymous. Al-Mausua Al-Arabia Al-Aalamia from Kutub Al-Shamila. Al-Maktab Al-Ta'wuni Li Al-Da;wati Bi Al-Rauza: Mohammaed Abdulaziz Al-Rajhi Endowments.

9. Basavaraja KR. History and Culture of Karnataka. Chalukya publication Dharwad. 1984:279,545.

10. Chhabra GS. Advanced Study in the History of Modern India. Vol.I. Reprint 2nd ed. New Delhi; Strerling Publishers Pvt. Ltd.: 1984:300

11. Nadvi MI. Seerat Tipu Sultan Shaheed. 1st ed. Lucknow: Majlise Tahqiqat wa Nashriyate Islam; Dec 1996:162,480,481,498,499.

12. Usmani MS. Tipu Sultan Ke Molajat Wa Tikniki Tajarbat. 1st ed. Delhi: Majlise Tahqiqate Tibbi;1976:27-52.

13. Bangalori Mahmood. Tarikh-e-Saltant-e-Khudadad. 2nd ed. Bangalore; Barqi Kausar Press Ma'skar: 1939:428, 436, 441, 443, 452, 459, 463, 507.

14. Ahmad KJ. Hundred Great Muslims. 1st ed. Des Plaines: Library of Islam;1923:418.

15. Stewart C. Descriptive Catalogue of the Oriental Library of the Late Tipu Sultan of Mysore. 1se ed. London: Sold by Logman, Hurst, Rees, and Orme; 1809) by Major Charles Stewart.

16. Tipu Sultan. Select Letters of Tippoo Sultan to Various Public Functionaries (arranged and Translated in english by William Kirkpatrick). 1st ed. London: Printed by Cox, Son, and Baylis, Great Queen Street, Lincoln's-Inn-Fields.1811.

17. Nadwi M Ilyas. Tipu Sultan (A Life History), pp. 293-94. (http:// iosworld.org/April04_1.htm)

18. Zakaria Virk. Science in India during the Muslim Rule. https:// www.alislam.org/egazette/articles/Science-in-India-duringthe-Muslim-Rule.pdf dated 23.06.2016.

19. Murthy Srinivasa HV. Aspect of Karnataka History and Culture. Cambridge publishing Pvt. Limited. 2001:153-58.

20. Mahmud Husain Khan. En.m.wikipedia.org/wiki/Mahmud_ Husain. Last edited on 27 June 2016, accessed on 13.07.2016.

21. Lewis RB. Mysore A Gazetter Compiled for Government. Vol.I. New Delhi. Madras: Asian Educational Services;2001:599.

22. Wilks M. Historical Sketches of the South India in the Attempt to trace the History of Mysore. Vol.II. New Delhi. Madras: Asian Educational Service. 1989:334.

23. Suryanath U K. Gazetteer of India, Karnataka state gazetteer part II. Government of Karnataka Publication. 1983.674) (Hassan District. Gazetter of india Mysore State. Printed. Government Press.1971.554.

24. Lewis B. British Assessments of Tipu Sultan's Hill Forts in Northern Mysore, South India, 1802.Int J Histor Archaeol;2012 16:164-198. DOI 10.1007/s10761-012-0172-3)

25. Anonymous. Annual Repot of the Mysore Archaeological Department for the year 1935. Bangalore; Government Press:1936:54

26. Haroon A. Kingdom of Hyder Ali and Tipu Sultan: Sultanat e Khudadad. USA;Xlibris Corporation:2013:295

27. Charles Stewart. A Descriptive Catalogue of the Oriental Library of the Late Tippoo Sultan of Mysore. London; Cambridge University Press: 1809:94.

28. Kirmani HA. The History of the Reign of Tipu Sultan, Being A Continuation of The Neshani Hyduri. (translated by Colonel W. Miles). London; Printed by W.Nicot, Shakspears Press, Pall Mall: http://books.google.com. 
29. Buchanan F. A Journey from Madras through the Countries of Mysore, Canara and Malabar. Vol.I. 2nd ed. Madras; Forgotten Books:2013:345.

30. Bowring LB. Rulers of India Haibar Ali and Tipu Sultan (Edited by Sir William Wilson Hunter). London; Oxford the Clarendon Press:1899.

31. Kauser K. Secret Correspondence of Tipu Sultan. Bangalore. Published by Karnataka state archieves. 1998.311.
32. Fernandes Praxy. The Tigers of Mysore. Delhi. Reprinted. Ananda offset Pvt Ltd.1991:204.

33. Scurry J. the Captivity, Sufferings, and Escape. London; Henry Fisher, 38, Newgate-Street:1824.

34. SAKI. Making History Karnataka's People and their past. Vol. I, 1st ed. Shimoga; Vimukthi Parkashana:1998:552.

35. Author unknown. Authentic Memoirs of Tippoo Sultan. Calcutta; Reprint The Mieror press:1819:21. 